\title{
Effect of levamisol and vitamine E/selenium on bovine cellular and humeral immunity after bovine viral diarrhea vaccination
}

\begin{abstract}
The aim of the present study was to determine the effect of levamisol and vitamine E/ selenium on bovine immunity associated with Bovine viral diarrhea (BVD) vaccination. Fifteen mixed breed calves at (Age, 5-8months) of age in a private farm were used. Experimental animals were allocated randomly into 5 groups (3 each). Group 1 injected by Pneumo-3 vaccine (double doses of $5 \mathrm{ml}$ i.m with two weeks interval). Group 2 received Pneumo-3 vaccine and levamisole subcutaneously at a dose rate of $2 \mathrm{mg} / \mathrm{kg}$ b.w for 2 successive times (3days apart). Meanwhile, Group 3 received Pneumo-3 vaccine plus vitamin E/Selenium at a dose rate of $2 \mathrm{ml} / 40 \mathrm{~kg}$ b.w, i.m, for 3 successive times (seven days interval). For group 4, Pneumo-3 vaccine plus levamisole and vitamin E/selenium (as previously mentioned) were administered. However, group 5 received only levamisole and vitamin E/selenium combination. Host humoral and cellular immune responses were evaluated before vaccination and at $2,4,8,12,16,20$, and 24 weeks post-vaccination. A significant effect of time and treatment (ANOVA $\mathrm{P}<0.01$ ) were recorded. The antibody titer against BVD virus in vaccinated calves reached its peak level at 8 weeks from first injection. The highest level of antibodies against BVD virus was observed in calves administered Pneumo-3 plus levamisole Hcl plus vitamin E and selenium. However, the apoptotic lymphocytes index and Acridine orange stain ( $\mathrm{AO}$ ) was parallel; the apoptosis was found to be the highest in second group and the lowest in third group. Agarose gel electrophoresis for DNA of apoptotic lymphocytes showed fragmentation of DNA. The results of the present study indicate that using of Pneumo-3 vaccine together with vitamin E selenium and levamisol could induce a good humoral and cellular response to BVD in calves.
\end{abstract}

Keywords: levamisol hcl, bovine, cellular and humoral immunity, vaccination, vitamine e/selenium
Volume 2 Issue I - 2015

\author{
Mohamed Sayed-Ahmed, ${ }^{1,2}$ Samar Atwa, ${ }^{\prime}$ \\ Emad EYounis,' Said A Zeidan ${ }^{3}$ \\ 'Department of Internal Medicine and Infectious Diseases, \\ Mansoura University, Egypt \\ ${ }^{2}$ Department of Clinical Pharmacy, Jazan University, Saudi Arabia \\ ${ }^{3}$ Rinderpestlike Diseases Department, Veterinary Serum and \\ Vaccine Research Institute, Egypt
}

Correspondence: Mohamed Sayed-Ahmed, Department of
Infectious Diseases, College of Veterinary Medicine, Mansoura
University, Mansoura 355I6, Egypt, Tel 0096659488 6878, Fax 0096617321 6837, Email drzakarial0I@yahoo.com

Received: December 25, 2014 | Published: March 23, 2015
Abbreviations: AO, acridine orange stain; BVD, bovine viral diarrhea; BVDV, bovine viral diarrhea virus; NCP-BVDV, non cytopathic-bovine viral diarrhea virus; GSH, glutathione; TCID $_{50}$, tissue culture infected dose 50; dpi, day post infection; MDBK, madin darby bovine kidney; HBSS, hank's balanced salt solution; SNT, serum neutralization test; PBS, phosphate buffer saline; HEPES, (4-(2-hydroxyethyl)-1-piperazineethanesulfonic acid); NS3, non-structural protein 3; PBLS, peripheral blood lymphocytes

\section{Introduction}

Bovine viral diarrhea is one of the production limiting diseases in dairy herd as it interferes with reproductive and immunological functions. ${ }^{1}$ BVDV can affect the cell mediated immunity in buffalo with noticeable effect on humoral mechanism. ${ }^{2}$ The success of vaccination aimed at increasing immunity and reducing the risk of infection. The transmission is likely depending up on the homogenicity between the vaccine strains and the field strains present in the herd. The more homologous the strains, the more cross- protection will be achieved. The goal of immunization is to stimulate both the B- and T-cell arms of the immune system. The B-cell has the major responsibility for inactivating free virus that achieved primarily by immunoglobulin, which neutralizes the BVDV infectivity and secondarily aggregated
BVDV and enhances clearance. Cell- mediated immunity, particularly $\mathrm{CD}_{4+}$ cells type 2, which is important for the resolution of acute infection with non- cytopathogenic BVDV (NCP BVDV). ${ }^{3}$

Selenium and Vitamin E independently enhance the immune response of lambs challenged with a viral pathogen. Selenium and vitamin E deficiency could compromise the immune system and result in a decline in resistance of animals to infections. ${ }^{4}$

Levamisole seems to potentiate 5-fluorouracil's antiproliferative effect in different tumor cell lines possibly by modulation of phosphorylation processes relevant for both cell cycle progression and apoptosis and this also for endothelial cells. ${ }^{5}$ Levamisole induces apoptosis and growth arrest in cultured vascular endothelium to be associated with a loss of survival and antioxidative factors as well as with induction of growth arrest/death signals. ${ }^{6}$ Such Levamisol induces apoptosis seems to relate to oxidative stress which is counteracted by the antioxidants GSH and N-Ac and thus possibly depends on exhausting of GSH and/or a concomitant increase of intracellular $\mathrm{H}_{2} \mathrm{O}_{2}{ }^{7}$

To the best of our knowledge, scare studies are available on use of levamisole and vitamins $\mathrm{E}$ for modulate the immune response 
associated with BVD vaccination. Therefore, the objective of the present study was to assess effect of levamisol and vitamine E/ selenium on bovine cellular and humeral immunity after bovine viral diarrhea vaccination.

\section{Materials and methods}

\section{Animals}

A total of fifteen clinically normal calves (age, 5-8months) at a private farm in Dakahlia Governorates, Egypt were used. Calves were randomly selected and allocated into five groups (3 each). Calves were fed on concentrated ration. Animals were not vaccinated for BVD.

\section{Vaccine}

A combined inactivated respiratory virus's vaccine (pneumo-3, Veterinary Serum and Vaccine Research Institute, Cairo, Egypt) was used. The vaccine is used for protection against BVD, IBR, and PI3.

\section{Cell culture}

Madin Darby Bovine kidney (MDBK) cell line was used for both viral isolation and SNT. ${ }^{8}$ The cell line was proved to be free from noncytopathic BVD virus.

\section{Virus strains}

BVDV genotype-1 and BVDV genotype-2 strains were used. A Local strain of BVDV genotype-1 cytopathic strain (Iman-strain, Veterinary Serum and Vaccine Research Institute, Cairo, Egypt) was used for serological tests. The $\operatorname{TCID}_{50}$ per $100 \mu l=10^{5}$ at 14 days post infection (dpi). ${ }^{9}$ BVDV genotype- 2 is strain 125 of BVDV genotype- 2 cytopathic strains (Ames Iowa Laboratories, USA). The TCID $_{50}$ per $100 \mu \mathrm{l}=10^{5}$ at $14 \mathrm{dpi}$. For indirect fluorescent antibody technique BVDV antiserum (Veterinary Serum and Vaccine Research Institute, Cairo, Egypt) was used.

\section{Experimental vaccination}

Experimental animals were allocated randomly into 5 groups (3 each). Group 1 injected by Pneumo-3 vaccine (double doses of $5 \mathrm{ml}$ i.m with two weeks interval). Group 2 received Pneumo-3 vaccine (as previously mentioned) and levamisole (Ucimisole ${ }^{\circledR}$ Norbrook Laboratories, UK) subcutaneously at a dose rate of $2 \mathrm{mg} / \mathrm{kg}$ b.w for 2 successive times, 3days apart. Meanwhile, Group 3 received Pneumo-3 vaccine plus vitamin E/Selenium (Vitesel ${ }^{\circledR}$, Norbrook Laboratories, UK) at a dose rate of $2 \mathrm{ml} / 40 \mathrm{kgb} . \mathrm{w}, \mathrm{i} . \mathrm{m}$, for 3 successive times (seven days interval). For group 4, Pneumo-3 vaccine plus levamisole and vitamin E/selenium (as previously mentioned) were administered. However, group 5 received only levamisole and vitamin E/selenium combination.

\section{Blood samples}

Two blood samples were collected from each calve before vaccination and at $2,4,8,12,16,20$, and 24 weeks post-vaccination for serum. One of the blood samples was collected on EDTA for lymphocyte separation for estimation of cellular immunity, whereas the second sample was collected into tube without anticoagulant for obtaining serum.

\section{Virus titration}

Serial tenfold dilution of used viruses was prepared in cold HBSS. $0.1 \mathrm{ml}$ of each dilution was inoculated into each of four tissue culture tubes. Culture tubes were incubated at $37^{\circ} \mathrm{C}$ for two hours. Then maintenance media was added. Tubes were incubated at $37^{\circ} \mathrm{C}$; media and were changed every three days. Culture was observed microscopically for specific cytopathic effect for 2 weeks. Virus titer was calculated according to standard method. ${ }^{10}$ Titer was expressed as $\mathrm{TCID}_{50}$ per $0.1 \mathrm{ml}$ of used viruses and was kept frozen till used for Serum Neutralization Test (SNT).

\section{Serum Neutralization Test (SNT)}

The test was performed using flat bottom sterile micro-plates according to Cerberey and Lee. ${ }^{11}$

Lymphocyte separation: Cells well obtained from whole blood using lymphocyte-separation solution (Ficoll-Hypaque Pharmacia, Uppsala, Sweden). ${ }^{12}$ Lymphocytes were washed twice with sterile PBS pH 7.6. Cells were suspended at 107/ml in RPM1 1640 (GIBCO) containing $25 \mathrm{mM}$ glucose $20 \mathrm{mM}$ L-glutamine, $92 \mu \mathrm{m}$ gentamicin $20 \mu \mathrm{gml}$. (Walkersvlle MD) and 25mM HEPES buffer (pH 7.3, GIBCO). Cells were suspended in sterile PBS (PH 7.2). The cell suspension were divided into 4 aliquots to measure the apoptosis at zero time (base time), then 24,48 , and $72 \mathrm{~h}$, cells were incubated (at $37^{\circ} \mathrm{C}$ in $5 \%$ carbon dioxide). After incubation, cells were centrifuged (200xg, $5 \mathrm{~min}$ ), suspended in ice-cold- cold PBS and analyzed on a coulter counter. At time 0 and then at subsequent times, cells were removed from culture and counted on a hemocytometer. Cell viability was determined by trypan blue dye exclusion test, in which one volume of trypan blue $(0.4 \%$, GIBCO) was added to 5 volumes of cells at room temperature for 5 minutes.

\section{Detection of apoptotic cells}

At time zero and at subsequent times, cells were removed from each culture, fixed in methanol, harvested on slides stained with May Grunwald Giemsa for assessment of the percentage of cells showing morphology of apoptosis. ${ }^{13}$ By using oil immersion light microscope, the apoptotic lymphocyte percentage at different times was calculated. To identify engulfed apoptotic cells, acridine orange stain (AO) was used. Briefly, one drop of cell suspension was added to one AO solution $(10 \mu \mathrm{g} \mathrm{ml}$ in PBS), mixed gently on a slide and immediately examined with an Olympus HB-2 microscope with fluorescence attachment. ${ }^{14}$

Assessment of apoptotic index: For this analysis in each case, the mean number of monocytic cells per field was registered in 15 randomly chosen fields. The apoptotic bodies were then counted in greater number of fields and expressed as percentages monocytic cells per case. ${ }^{15}$

DNA fragmentation: Total DNA was extracted with $0.5 \mathrm{ml}$ saturated phenol followed by chloroform and isoamyl alcohol (24:1) before centrifugation at $7000 \mathrm{~g}, 4^{\circ} \mathrm{C}$ for 10 minutes. DNA in the supernatant was precipitated by adding $0.02 \mathrm{ml}$ of $5 \mathrm{~m} \mathrm{NaCl}$ and $1 \mathrm{ml}$ of absolute ethanol. After centrifugation at $9500 \mathrm{rpm}$ for 15 minutes, the pellets were air-dried prior to suspending in $0.1 \mathrm{ml}$ TE buffer $(10 \mathrm{mM}$ TrisHcl, pH 8.0, 1mM EDTA). RNA was eliminated by Rnase digestion $(0.1 \mathrm{mg} \mathrm{ml} \mathrm{Rnase,} \mathrm{incubated} \mathrm{at} \mathrm{room} \mathrm{temperature} \mathrm{for} \mathrm{1hour).} \mathrm{The}$ DNA was electrophorsed using $1.8 \%$ agrose gel and visualized by ethidium bromide staining. ${ }^{16}$

\section{Statistical analysis}

Statistical analysis was carried out using GMP, SAS commercial 
statistical software program. Repeated measures MANOVA (with repeated measures on treatment and time) were used to determine the main effect of dose and time. Wilks' Lambda test was selected to evaluate within group interactions and evidence of time group interactions. Where Wilks' Lambda test indicated a statistically significant difference between groups, one way ANOVA with TukeyKramer HSD post-hoc multiple comparison tests was used to identify which group was statistically different from the rest. Differences between means at $p<0.05$ were considered significant.

\section{Results}

\section{Humoral response}

Antibody titer was affected significantly by time and treatment
$(\mathrm{P}<0.01)$. The antibody titer against BVD virus in vaccinated calves reach peak of its level at second month from first injection (Table 1). The highest level of antibody titer against BVD virus in vaccinated calves was observed in calves administered Pneumo-3 plus Levamisole Hcl plus vitamin E and selenium.

\section{Cellular response}

The apoptotic lymphocytes index detected by Giemsa and A.O are parallel. The apoptosis was found to be higher (p-value) in the group 2 and lower (p-value) in the group 3 but no significant difference between both group 1 and group 2 was found (Table 2) (Figure 1). Agarose gel electrophoresis for DNA of apoptotic lymphocytes showed fragmentation of DNA as showed in Figure 2.

Table I BVDV antibodies titer detection by SNT in different vaccinated groups

\begin{tabular}{|c|c|c|c|c|c|c|c|c|}
\hline \multirow[b]{2}{*}{ Groups } & \multicolumn{8}{|c|}{$\log _{10}$ BVD SNT post vaccination/week (mean \pm SD) } \\
\hline & 0 & 2 & 4 & 8 & 12 & 16 & 20 & 24 \\
\hline Group I & $I . I \pm 0 . I^{\mathrm{a}}$ & $1.4 \pm 0.17^{\mathrm{a}}$ & $1.6 \pm 0 . I^{\mathrm{a}}$ & $1.7 \pm 0.17^{\mathrm{a}}$ & $2.0 \pm 0.1^{\mathrm{a}}$ & $1.6 \pm 0.17^{\mathrm{b}}$ & $1.1 \pm 0.1$ & $0.8 \pm 0.17$ \\
\hline Group 2 & $1.3 \pm 0.1^{a}$ & $1.5 \pm 0.00 \mathrm{I}^{\mathrm{a}}$ & $1.6 \pm 0.1^{\mathrm{a}}$ & $1.8 \pm 0.00 \mathrm{I}^{\mathrm{a}}$ & $2.0 \pm 0 . I^{\mathrm{a}}$ & $2.1 \pm 0.00 I^{\mathrm{a}}$ & $1.2 \pm 0.001$ & $0.8 \pm 0.1$ \\
\hline Group 3 & $1.3 \pm 0.1^{a}$ & $1.5 \pm 0.30^{\mathrm{a}}$ & $I .0 \pm 0 . I^{\mathrm{a}}$ & $2.0 \pm 0.17^{\mathrm{a}}$ & $2.2 \pm 0 . I^{\mathrm{a}}$ & $2.1 \pm 0.30^{\mathrm{a}}$ & $1.3 \pm 0.1$ & $0.8 \pm 0.1$ \\
\hline Group 4 & $1.4 \pm 0.1^{a}$ & $1.6 \pm 0.17^{\mathrm{a}}$ & $I .0 \pm 0 . I^{\mathrm{a}}$ & $2.0 \pm 0.17^{a}$ & $2.3 \pm 0.1^{\mathrm{a}}$ & $2.3 \pm 0.17^{a}$ & $I .5 \pm 0.00 I^{\mathrm{a}}$ & $0.7 \pm 0.1$ \\
\hline Group 5 & $0.4 \pm 0.1^{b}$ & $0.3 \pm 0.00 \mathrm{I}^{\mathrm{b}}$ & $0.4 \pm 0.1^{b}$ & $0.7 \pm 0.17^{b}$ & $0.8 \pm 0.1^{b}$ & $0.6 \pm 0.00 I^{c}$ & $0.8 \pm 0.1^{b}$ & $0.7 \pm 0.1$ \\
\hline
\end{tabular}

The variables with different superscript letters at the same columns are significantly different at $\mathrm{P}<0.05$

Table 2 The mean percentage of pBLs by acridine orange stain $(\mathrm{AO})$ in different vaccinated groups

\begin{tabular}{lllll}
\hline Tested group & $\mathbf{0}$ time & $\mathbf{2 4} \mathbf{~ h r s}$ & $\mathbf{4 8 ~ h r s}$ & $\mathbf{7 2} \mathbf{~ h r s}$ \\
\hline First group & $16.4 \pm 0.3$ & $13.27 \pm 0.4$ & $10.53 \pm 1.1$ & $8.03 \pm 0.4^{\mathrm{b}}$ \\
Second group & $15.20 \pm 0.6^{\mathrm{b}}$ & $13.17 \pm 0.6^{\mathrm{b}}$ & $10.27 \pm 0.7$ & $7.60 \pm 0.1$ \\
Third group & $15.30 \pm 0.7^{\mathrm{b}}$ & $12.53 \pm 0.3^{\mathrm{b}}$ & $10.03 \pm 0.5$ & $7.03 \pm 0.2^{\mathrm{y}}$ \\
Fourth group & $15.40 \pm 0.4^{\mathrm{b}}$ & $12.77 \pm 0.2^{\mathrm{b}}$ & $9.4 \pm 1.6^{\mathrm{b}}$ & $6.7 \pm 0.2^{\mathrm{c}}$ \\
Fifth group & $17.83 \pm 0.5^{\mathrm{a}}$ & $14.33 \pm 0.6^{\mathrm{a}}$ & $12.30 \pm 0.6^{\mathrm{a}}$ & $9.47 \pm 0.5^{\mathrm{a}}$ \\
\hline
\end{tabular}

The variables with different superscript letters at the same columns are significantly different at $\mathrm{P}<0.05$

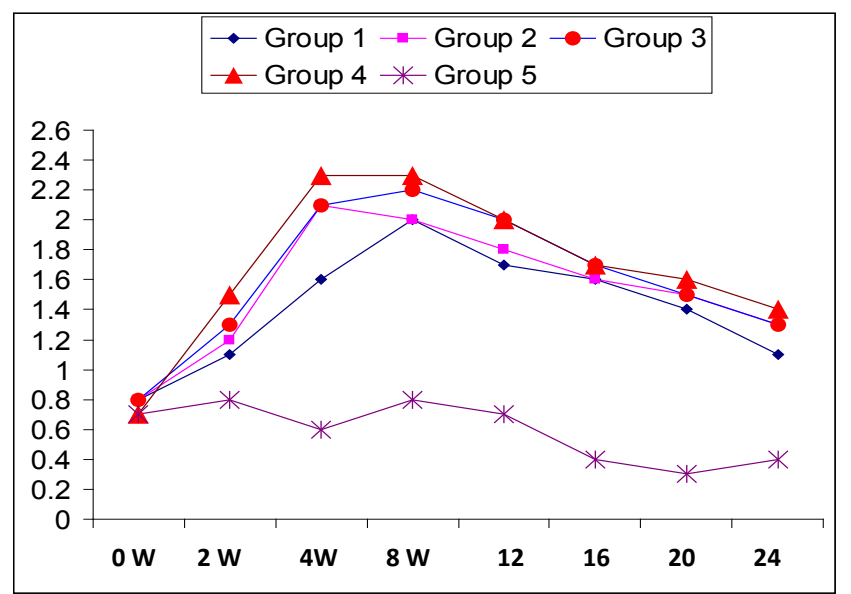

Figure I BVDV antibodies titer detection by SNT in different vaccinated groups.

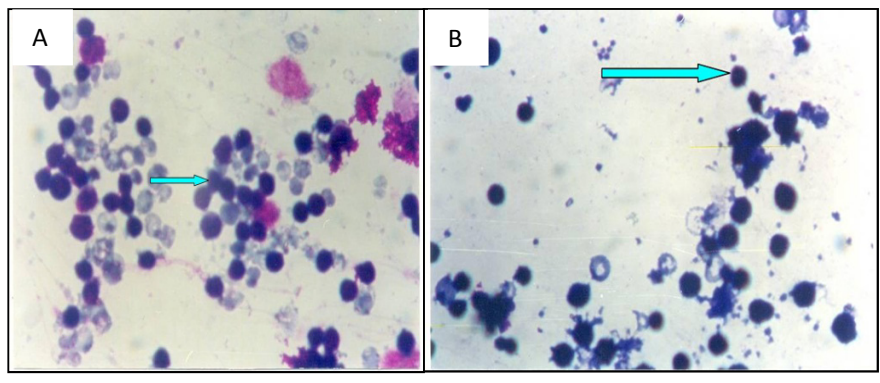

Figure 2 A photomicrograph of blood lymphocytes (PBLs).

In vitro culture in group 5A showing big number of apoptotic cells by Giemsa stain and group 4B showing low number of apoptotic cells by Giemsa stain.

\section{Discussion}

The concept of control of BVD infection has changed since the first description of the disease. Early attempts to control the infection were focused on preventing economic losses on a herd basis by 
prophylactic vaccination. No attempts were made to eradicate BVD systematically on a regional or national basis. ${ }^{17}$ Combined inactivated respiratory virus vaccines (pneumo-3 or pneumo-4 vaccine) were evaluated to control BVD infection in cattle. ${ }^{18}$

In the present vaccination trails, we used commercially available pneumo-3 vaccine (combined inactivated respiratory virus vaccine containing BVD, IBR and PI3 viruses) with Levamisole $\mathrm{Hcl}$ and vitamin $\mathrm{E}$ and selenium as nonspecific immunostimulants to study active immunity in cattle calves. Serum neutralization test has been used for quantization of antibodies against BVDV. The test is sensitive, mostly specific and relatively simple to be performed. ${ }^{19}$ The titers were expressed as the $\log 10$ of the inverse dilution, which protected $50 \%$ of the tubes as calculated by Reed and Munch ${ }^{20}$ methods according to Mayer. ${ }^{10}$ The antibody titer against BVD virus in vaccinated calves reach peak of its level at second month from first injection, where the highest level of antibody titer against BVD virus was observed in calves administered Pneumo-3 plus Levamisole Hcl plus vitamin E and selenium. Our results are in agreement with the results obtained by Allam ${ }^{21}$ who mentioned that SNT were increased at 28 days post initial vaccination and reach the highest level by the day 60 post initial vaccination. Antibody titer was estimated by SNT through collection of sera samples at 0day, 2 weeks, 4weeks, 8 weeks, 12 weeks, 16 weeks, 20 weeks and 24 weeks post vaccination according to Fulton et al., ${ }^{22}$ who inoculated multiple groups of cattle at different times to detect the optimal time of vaccination by using of inactivated polyvalent vaccine containing BVD, IBR, PI-3 and BRSV. They vaccinated at 0day and day 14 .

Ghally et al. ${ }^{23}$ compared between local combined inactivated respiratory viruses vaccine containing IBR, BVD and PI-3 (pneumo-3) and imported vaccine containing modified live PI-3, IBR viruses and inactivated BVD virus (cattle master 4). The authors reported that both vaccines provide a very good protective level against challenge.

On using the immunostimulants the higher titer of antibodies was observed in the group 4, which administered Pneumo-3 vaccine plus levamisole Hcl plus vitamin E and selenium. Immunostimulants can be potentially used to stimulate the immune system and decrease the amount of antibiotics used for BVD. Vaccination stimulates the immune system to produce antibodies to specific pathogens. This method of immunomodulation has been in use for over 100years, but doesn't always produce the desired results. Non-specific immunostimulants can be used to enhance the immune responses prior to, following, or at vaccinations. They may also help the animal's immune system overcome the immunosuppressive effects of stress and exposure to infectious agents involved with BVD. ${ }^{24}$ There are many drugs used to increase the resistance of the animal by improving the humeral and cellular immune response such as vitamin $\mathrm{E}^{25}$ and selenium, ${ }^{26}$ where they appear to provide an efficient method of stimulating the immune system in a non-specific manner with few adverse side effects. Immuno stimulating compounds have the potential to counteract the effect of environmental or microbial immuno-suppressive factors. They may thus reduce morbidity and economic losses resulting from subclinical or mild infectious diseases. ${ }^{3}$

The exact mechanism by which levamisole could enhance serum antibody response to infective agents is not known. It has been reported that levamisole enhances macrophage and T-lymphocyte function and reduces suppressor T-cell function. Because antibody formation to most infectious agents is T-lymphocyte- dependent, the augmentation of the helper functions of these cells could enhance antibody production. ${ }^{27}$ Levamisole hydrochloride effects on humoral and cellmediated immune response in several diseases have been examined. ${ }^{28}$ Levamisole described as antiproliferative and affect both adhesion and $\mathrm{MHC}$ class I molecule expression. ${ }^{29}$ Endothelial cells exposed to levamisole exhibited considerable vacuolization and increased rates of apoptotic cell death as apparent by condensation of chromatin and the presence of apoptotic vesicles when compared to their individual control cells without added levamisole. ${ }^{2}$ Levamisole selectively induces apoptosis in cultured vascular endothelial cells from different origins, but not accompanying fibroblasts. The observed induction of endothelial apoptosis by levamisole may explain its impact as an adjuvant in cancer treatment relating to vascular targeting. ${ }^{30}$

Selenium is considered one of the most promising candidates for preventing cancer and when combined with vitamin E, they produced a synergistic effect on cell growth suppression due to the two agents working in tandem to cause further delay in cell cycle transit. ${ }^{31} \alpha-$ tocopheryl succinate is the most commonly used form of vitamin $\mathrm{E}$ in vitro studies of cancer research. It is generally assumed that because $\alpha$-tocopheryl succinate is less hydrophobic than $\alpha$-tocopherol, it is taken up more efficiently by cells. ${ }^{32}$

Cytopathic biotype of BVDV was able to kill cells by apoptosis in PBMC cultures while the homologous non-cytopathic virus could not. ${ }^{33}$ Cytopathic virus triggers apoptosis in monocytes by the expression of specific BVDV proteins rather than virus replication in infected cells. In this regard, the viral protein NS3 is likely candidate because it is a non-structural protein restricted to cytopathic viruses. ${ }^{34}$ The fact that NS3 has proteinase activities in intriguing, since apoptosis may be triggered by certain proteinases in variety of cell types. ${ }^{35}$ The apoptotic lymphocytes index detected by Giemsa and A.O are parallel. The apoptosis was found to be higher in the second group and lower in the third group but no significant difference between either first group or second group. Agarose gel electrophoresis for DNA of apoptotic lymphocytes showed fragmentation of DNA. These results was also recorded by Stern et al., ${ }^{36}$ and McDonald et al., ${ }^{37}$ who stated that apoptotic cell recognition and removal by phagocytes is critical for the restoration and/or maintenance of normal tissue structure and function. Macrophages engulf apoptotic cells before they lyse, thus preventing release into the tissue of potentially toxic and immunogenic intracellular substances. In addition, the binding and or uptake of apoptotic cells not only fail to induce macrophage secretion of inflammatory mediators, but actually inhibit their proinflammatory cytokine production following stimulation.

\section{Conclusion}

The results of this study highlight the importance of using Pneumo-3 vaccine together with vitamin E and Levamisole as nonspecific immunostimulant to induce good humoral and cellular response to improve the calves' resistance to BVD.

\section{Acknowledgements}

None.

\section{Conflict of interest}

Author declares that there is no conflict of interest. 


\section{References}

1. Radostitis OM, Gay CC, Hinchcliff $\mathrm{KW}$, et al. Veterinary medicine. $A$ Textbook of the diseases of cattle, horses, sheep, pigs and goats. 10th ed. Spain: Saunders El Sevier; 2006. p. 1248-1276.

2. Shalaby MA, El Sanousi AA, El Bagoury GF, et al. Effect of bovine viral diarrhea on immune response of Egyptian buffalo calves. Vet Med J. 1992;3:101-110.

3. Goyal SM, Ridpath JF. Bovine Viral Diarrhea Virus, Diagnosis, Management, and Control. USA: Wiley-Blackwell; 2005. p. 261.

4. Finch JM, Turner RJ. Effects of selenium and vitamin E on the immune responses of domestic animals. Res Vet Sci. 1996;60(2):97-106.

5. Yang C, Chang J, Gorospe M, et al. Protein tyrosine phosphatase regulation of endothelial cell apoptosis and differentiation. Cell Growth Differ. 1996;7(2):161-171.

6. Yamane D, Zahoor MA, Mohamed YM, et al. Microarray analysis reveals distinct signaling pathways transcriptionally. Virus Res. 2009;142(1-2):188-199.

7. Artwohl M, Holzenbein T, Wagner L, et al. Levamisole induced apoptosis in cultured vascular endothelial cells. $\mathrm{Br} J$ Pharmacol. 2000;131(8):1577-1583.

8. Marcus SJ, Moll T. Adaptation of bovine viral diarrhea virus to Madian Derby Bovine Kidney cell line. Am J Vet Res. 1968;29(4):817-819.

9. Baz TI. Isolation, characterization and serological studies on BVD-MD virus in Egypt. 1975.

10. Mayer A. Introduction of paraimmunity in biological products for viral disease. Munch Symposium Microbial. Francis and Verlag; 1981. p. 201-228.

11. Cerberey EA, Leem A. SNT for BVD and IBR viruses' emplying established tissue culture cell lines. Pro. 69th Annual meet. US livestock Saint Ass.501.1996.

12. Boyum A. Isolation of mononuclear cells and granulocytes from human blood. Scand J Clin Lab Invest. 1968;21(Suppl 97):77-83.

13. Wyllie AH, Morris A. Hormone induced cell death purification and properties of the thymocytes undergoing apoptosis after glucocorticoid treatment. AM J Pathol. 1985;109(1):78-87.

14. Kumagai M, Coustan-Smith E, Murray DJ, et al. Murry ligation of CD38 suppressor human B lymphopiosis. J Exp Med. 1995;181(3):1101-1110.

15. del Vecchio MT, Leoncini L, Buerki K, et al. Diffuse centrocytic and/ or centroblastic malignant non-Hodgkins lymphomas comparison of mitotic and pyknotic (apoptotic) indices. Int J Cancer. 1991;47(1):38-43.

16. Maruyama W, Shinji I, Sato T. Morphological changes in the nucleus and actin cytoskeleton in the process of Fas-induced apoptosis in Jurkat T-cells. Histochem J. 2000;32(8):495-503.

17. Moennig V, Houe H, Lindberg A. BVD control in Europe: current status and perspectives. Anim Health Res Rev. 2005;6(1):63-74.

18. El-Sabbagh MM, El-Sawalhy AA, Samira S, et al. Epidemiological studies on IBR, BVD, PI - 3 and Bovine Adeno virus in calves of Governorates in Egypt. Minufiya Vet J. 2000;1(1):373-387.

19. Rossi CR, Kiessel GK. Microtitre tests for detecting antibody in bovine serum to PI-3 virus, IBRV and BVDV. Microbiol. 1971;22:32-36.
20. Reed LJ, Muench H. A simple method for estimating 50\% end points. Am J Epidemiol. 1938;27(3):493-497.

21. Allam A. Study on combined inactivated respiratory virus's vaccine. Benha University. 2006. p. 1-193.

22. Fulton RW, Confer AW, Burge LJ, et al. Antibody viral vaccines containing BHV,BVD,PI-3 and BRSV immunogens and subsequent revaccination at day 140. Vaccines. 1995;13(8):715-733.

23. Ghally HM, El-Sabbagh MM, Taha M. Effects of local combined inactivated respiratory virus vaccine on FMD vaccination. Assuit Vet Med J. 2001;39(75):79-89.

24. Quinn PJ. Advances in Veterinary Science and Comparative Medicine: Immunomodulation in Domestic Food Animals. In: Blecha F, Charley B, editors. Boston, USA: Academic Press; 1990;35:66-67.

25. Politis S, Hidiroglou N, White J, et al. Effects of vitamin E on mammary and blood leukocyte function, with emphasis on chemotaxis in periparturient dairy cows. Am J Vet Res. 1996;57(4):468-471.

26. Braun U, Forrer R, Furer L, et al. Selenium and vitamin E in blood sera of cows from farms with increased incidence of diseases. Vet Rec. 1991;128(23):543-547.

27. Babiuk LA, Misra V. Effect of levamisole in immune responses to bovine herpes virus-1. Am J Vet Res. 1982;43(8):1349-1354.

28. Confer AW, Lessley BA, Panciera RJ, et al. Serum antibodies to antigen derived from saline extract of pasturella haemolytica correlation with resistance to experimental bovine pneumonic pasturellosis. Vet Immuno Immunopathol. 1985;10(2-3):265-278.

29. Kimball ES, Fisher MC. Levamisole effects on major histocompatibility complex and adhesion molecule expression and on myeloid cell adhesion to human colon tumor cell lin. J Natl Cancer Inst. 1996;88(2):109-116.

30. Schnitzer JE. Vascular targeting as a strategy for cancer therapy. $N$ Engl J Med. 1998;339(7):472-474.

31. Ke Zu, Clement IP. Synergy between selenium and vitamin E in apoptosis induction is associated with activation of distinctive initiator caspases in human prostate cancer cells. Cancer Res. 2003;63(20):6988-6995.

32. Turley JM, Sanders BG, Kline K. RRR- $\boldsymbol{\alpha}$ - tochopheryl succinate modulation of human promyetocytic leukemia (HL-60) cell proliferation and differentiation. Nutr Cancer. 1992;18(3):201-213.

33. Zhang G, Aldridge S, Clarke MC, et al. Cell death induced by cytopathic bovine viral diarrhea virus is mediated by apoptosis. J Gen Virol. 1996;77(Pt 8):1677-1681.

34. Wiskerchen M, Collet MS. Pestivirus gene expression: Protein P80 of bovine viral diarrhea virus is a proteinase involved in polyprotein processing. Virology. 1991;184(1):341-350.

35. Steller H. Mechanisms and genes of cellular suicide. Science. 1995;267(5203):1445-1449.

36. Stern M, Savill J, Haslett C. Human monocyte-derived macrophage phagocytosis of senescent eosinophils undergoing apoptosis: mediation by $\alpha \mathbf{v \beta 3 / C D 3 6 / t h r o m b o s p o n d i n ~ r e c o g n i t i o n ~ m e c h a n i s m ~ a n d ~ l a c k ~ o f ~}$ phlogistic response. Am J Pathol. 1996;149(3):911-921.

37. McDonald PP, Fadok VA, Bratton DL, et al. Transcriptional and translational regulation of inflammatory mediator production by endogenous TGF- $\boldsymbol{\beta}$ in macrophages that have ingested apoptotic cells. $J$ Immunnol. 1999;163(11):6164-6172. 